\title{
Resistance patterns of microbes isolated from gastrointestinal tract
}

\author{
Mardiastuti H. Wahid, Ika Ningsih, Azmier Adib \\ Department of Microbiology, Faculty of Medicine, University of Indonesia, Jakarta, Indonesia
}

\begin{abstract}
Abstrak
Latar belakang: Infeksi saluran cerna dengan manifestasi klinis berupa diare merupakan penyakit infeksi dengan kesakitan dan kematian yang tinggi terutama di negara-negara yang sedang berkembang. Diare menimbulkan kematian terutama pada bayi baru lahir di bawah 1 tahun. Penanganan telah ditingkatkan secara terus menerus, namun demikian kemajuan dalam diagnosis maupun pengobatan tidak terjangkau oleh negara-negara yang sedang berkembang. Salah satu penyebab infeksi saluran cerna adalah bakteri. Oleh karenanya dengan mengetahui bakteri penyebab serta pola resistensi bakteri terhadap antibiotik dapat menunjang penatalaksanaan penyakit ini. Studi ini dilakukan untukmengetahui berbagai jenis mikroba yang diisolasi dari saluran cerna serta pola resistensinya terhadap beberapa antibiotik.
\end{abstract}

Metode: Spesimen berupa tinja, usap dubur atau anus yang diterima oleh Laboratorium Mikrobiologi FKUI selama 20052008. Isolasi, identifikasi kepekaan dan uji antibiotik dikerjakan sesuai prosedur standar yang berlaku. Interpretasi hasil uji kepekaan menggunaan panduan NCCLS/CLSI. Data dianalisis menggunakan WHOnet versi 5.3.

Hasil: Diperoleh 28 isolat Escherichia coli patogen, 1 isolat Salmonella paratyphi A, dan 4 isolat ragi yang diisolasi dari tinja dan swab dubur penderita. Walaupun Escherichia coli patogen masih peka terhadap beberapa antibiotik, namun kepekaannya menurun terhadap amoxicillin, sulbenicillin, ticarcillin dan trimethoprim/rulfamethoxazole.

Kesimpulan: Escherichia coli patogen merupakan bakteri terbanyak yang berhasil diisolasi dari tinja/usap dubur. Bakteri ini telah menunjukkan penurunan kepekaan terhadap beberapa antibiotikyang sering digunakan untukmengobati infeksi saluran cerna. (Med J Indones 2011; 20:105-8)

\begin{abstract}
Background: Digestive tract infection with clinical manifestation of diarrhea is an infectious disease that has the highest morbidity and mortality rate, especially in developing countries. Diarrhea causes mortality mostly in infants under one year old. Improvement in management is done continuously, but advances in diagnosis and therapy cannot be reached by developing countries. One of the etiological agents causing infection of digestive tract is bacteria. Therefore, knowledge of bacteria that cause gastrointestinal infection and their resistance patterns may support the management of this disease. The aim of this study was to examine microbes that were isolated from the digestive tract and their resistance patterns against antibiotics.

Methods: Samples (stool, rectal/anal swab) were collected from the Clinical Microbiology Laboratory, FKUI during 2005-2008. Isolation, identification and sensitivity test were conducted according to standard laboratory procedures. Interpretation of sensitivity test was done according to NCCLS/CLSI guidance. Data was analyzed using WHOnet version 5.3.

Results: We found 28 isolates of pathogenic Escherichia coli, 1 isolate of S. paratyphi A and 4 isolates of yeasts. Pathogenic Escherichia coli were still sensitive against some antibiotics, but the sensitivity was reduced against amoxicillin, sulbenicillin, ticarcillin and trimethoprim/sulfamethoxazole.

Conclusion: The most predominant gastrointestinal tract infection causing microbes was pathogenic Escherichia coli. These bacteria showed decrease sensitivity against some antibiotics commonly used to treat patients with gastrointestinal tract infection. (Med J Indones 2011; 20:105-8)
\end{abstract}

Key words: antibiotics, Escherichia coli, gastrointestinal infection

Infection of the gastrointestinal tract is one of important medical problems worldwide, especially in children. ${ }^{1}$ In developing countries such as in Asia, Africa and Latin America diarrheal diseases in children cause 12,600 deaths/day. ${ }^{2}$ The highest morbidity rates were found in children within 6-11 month age group; the mortality rates were highest in infants under 1 year old and children of one year old. Based on the estimation of 1980 population, the yearly morbidity and mortality in children under 5 years old in Africa, Asia (excluding China) and Latin America were 744-1000 million episodes and 4.6 million respectively. ${ }^{3}$ Recent report stated that the incidence of diarrhea for children under 5 years old in developing areas and countries was a median of 3.2 episodes/child/year, whilst the estimation of mortality rate was 4.9 children/1000/ year. ${ }^{4}$ Improvement and advances in diagnosis and treatment of diarrheal diseases was done continuously, though they still cannot be reached by many developing countries in the world. ${ }^{5}$

Gastrointestinal infections can be caused by bacteria, virus, fungi and parasites. ${ }^{2}$ Specifically for bacterial infection of digestive system, there are two 
major mechanisms. First, intoxication, the toxin is produced, ingested and cause symptoms. One of the most common organisms that cause intoxication is enterotoxin producing Stapylococcus aureus. Second, actual infection of the host cells, the pathogens produce toxin and result in host cell damage or death. Some organisms only adhere to the surface of epithelial cells and cause damage or death of the cells e.g. Enterotoxigenic Escherichia coli (ETEC). Others, after adhering, invade the cells and then damage them e.g. Campylobater, Salmonella, Shigella, Rotavirus, and Norwalk agent. Microbes can produce the symptoms of watery diarrhea (viral gastroenteritis) to bloody mucus (dysentery, Shigellosis), as well as invade into the bloodstream as enteric fever by Salmonella typhi. ${ }^{6}$

Therefore, to support the diagnosis and management of bacterial infection, we conducted a study to determine the types of bacteria that were isolated from the gastrointestinal tract and their antibiotic resistance patterns.

\section{METHODS}

The samples were collected from feces, rectal or anal swab of patients who came to the Clinical Microbiology Laboratory FKUI during 2005-2008. Rectal/anal swabs were mostly collected from healthy patients for the screening of Salmonella typhi carrier.

Isolation, identification and antibiotic sensitivity test were conducted according to the standard operational procedure applied in the laboratory.

\section{Isolation}

To isolate microorganisms, we streaked the specimens into enteric medium (eosin methylen blue and Salmonelashigella agar). The medium was then incubated at $37^{\circ} \mathrm{C}$, for 18-24 hours. Gram stain was only conducted to identify colonies that grow on the medium if necessary (mostly rod negative Gram).

\section{Identification}

To identify microbes into species level, we conducted conventional biochemical tests. Biochemical tests were based on carbohydrate fermentation, enzyme utilization and other chemical substance reaction/production. If there was any problem in identifying the isolated microbes, we conducted Microgen ${ }^{\mathrm{TM}}$ GN-ID test (a commercially available diagnostic kit) to identify the microbes.

\section{Antibiotic sensitivity tests}

Disc diffusion method, which is a method of choice for testing the sensitivity of some antibiotics against microorganisms, was used to test the microorganisms that were isolated from the specimens. We used some antibiotics, such as: amoxicillin, sulbenicillin, cefotiam, ceftriaxone, amikacin, chloramphenicol, trimethoprim/ sulfamethoxazole, ciprofloxacin, dibekacin, ofloxacin, cefepime, fosfomycin, piperacillin/tazobactam, levofloxacin, cefoperazone/sulbactam, meropenem and ticarcillin. The interpretation was based on the diameter of inhibition zone, which was seen as a clear zone that showed the ability of the antibiotics to inhibit the growth of the microbes. Antibiotic sensitivity test results were interpreted using NCCLS/CLSI guidance.

\section{Data collection and analysis}

The data collected were the types of isolated bacteria and their resistance patterns against some antibiotics. All data were noted, tabulated and presented in a graph. The data was analyzed using WHOnet version 5.3., to compute the percentages of antibiotics' resistance and presented in a graph.

\section{RESULTS}

The result showed that pathogenic E. coli was the predominant isolate found. Table 1 shows the microbes that were isolated from feces, rectal or anal swab. In 2007-2008, the numbers of samples were higher because we examined rectal swab/feces that were collected from hospital's and hotel's employees.

Table 1. Microbes isolated from feces/anal or rectal swab collected from Clinical Microbiology Laboratory FKUI 2005-2008.

\begin{tabular}{llcc}
\hline Year & \multicolumn{1}{c}{ Organisms } & Number of samples & Percentage (\%) \\
\hline 2005 & Pathogenic E. coli & 2 & 1.5 \\
& S. paratyphi A & 1 & 0.8 \\
& No pathogenic bacteria & 127 & 97.7 \\
& & & \\
2006 & Pathogenic E. coli & 9 & 7.8 \\
& No pathogenic bacteria & 95 & 92.2 \\
& & & \\
2007 & Pathogenic E. coli & 6 & 3.7 \\
& Yeast & 1 & 0.6 \\
& No pathogenic bacteria & 156 & 95.7 \\
& & 12 & 3.9 \\
2008 & Pathogenic E. coli & 3 & 1 \\
Yeast & 290 & 95.1 \\
No pathogenic bacteria & &
\end{tabular}

Figure 2 shows the resistance pattern of pathogenic E.coli against several antibiotics. From 2005-2008, the pathogenic E.coli showed a reduced sensitivity against some antibiotics such as ticarcillin (18.5\%), trimethoprim/sulfamethoxazole (14.8\%), sulbenicillin (11.5\%) and amoxicillin (11.1\%). Since the number of other bacteria was too small, we will not discuss their resistance patterns to avoid misleading. 


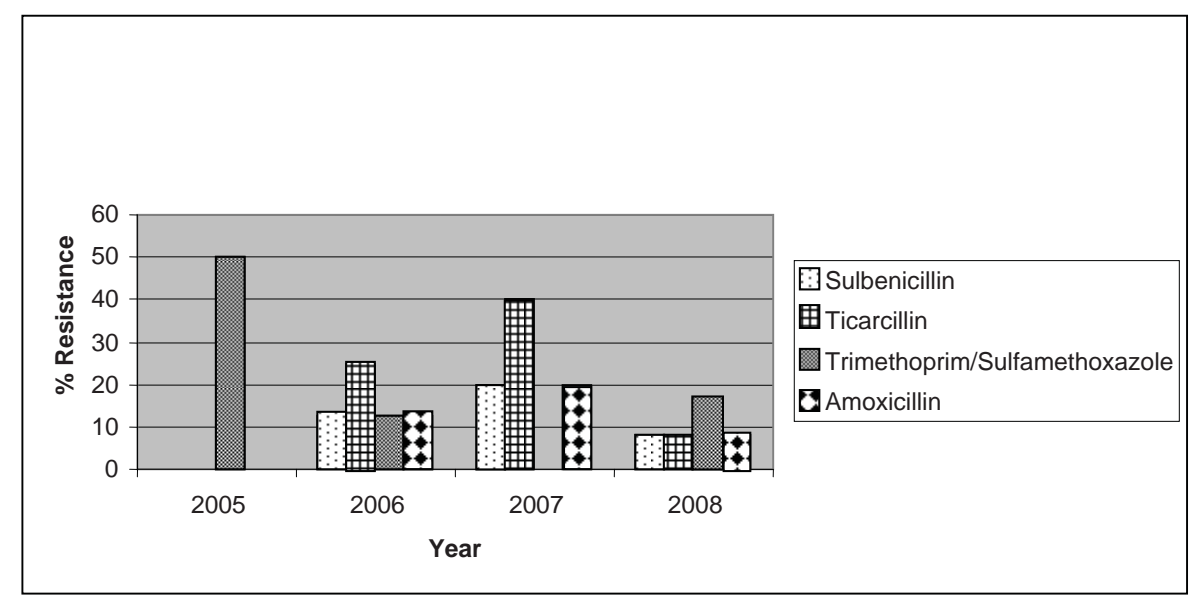

Figure 2.Resistance pattern of pathogenic E.coli against Amoxicillin, Sulbenicillin, Ticarcillin and Trimethoprim/Sulfamethoxazole 2005-2008

\section{DISCUSSION}

Infections of gastrointestinal tract may be localized and systemic, and a schematic representation is shown in figure $1 .^{7}$ Guerrant et $\mathrm{al}^{2}$ stated that the predominant microbes causing diarrhea in developing countries were enterotoxigenic Escherichia coli and rotavirus. Another study by Wasito and Bagus showed that in hospitalized children under 2 years old, E. coli (85.45\%) was found to be the most frequent organism isolated, followed by $K$. oxytoca (9.09\%), Salmonella sp (2.73\%), Vibrio cholerae (1.82\%), Shigella spp. (0.91\%) and rotavirus (27.99\%). It was interesting that in children under 2 years old many pathogenic bacteria such as V.cholerae, Salmonella and Shigella spp. were found in Wasito and Bagus' study.
Furthermore, Klebsiella oxytoca that is a member of normal flora was found as one of etiological agent of diarrhea in hospitalized children under 2 years old. ${ }^{8}$ A study conducted by Omololu-Aso et $\mathrm{al}^{9}$ found that five out of thirteen samples collected from patients (including a six month old baby) were positive for Salmonella. Salmonella isolated from the six month old baby was sensitive to amoxillin, cotrimoxazole, nitrofurantoin, gentamicin, ofloxacin and tetracycline, but was resistant to nalidixic acid and augmentin. The most prevalent Salmonella species found were Salmonella typhi and Salmonella paratyphi. There are many factors that may cause the presence of Salmonella in faeces, for example ingestion of contaminated food or drinking water. ${ }^{9}$

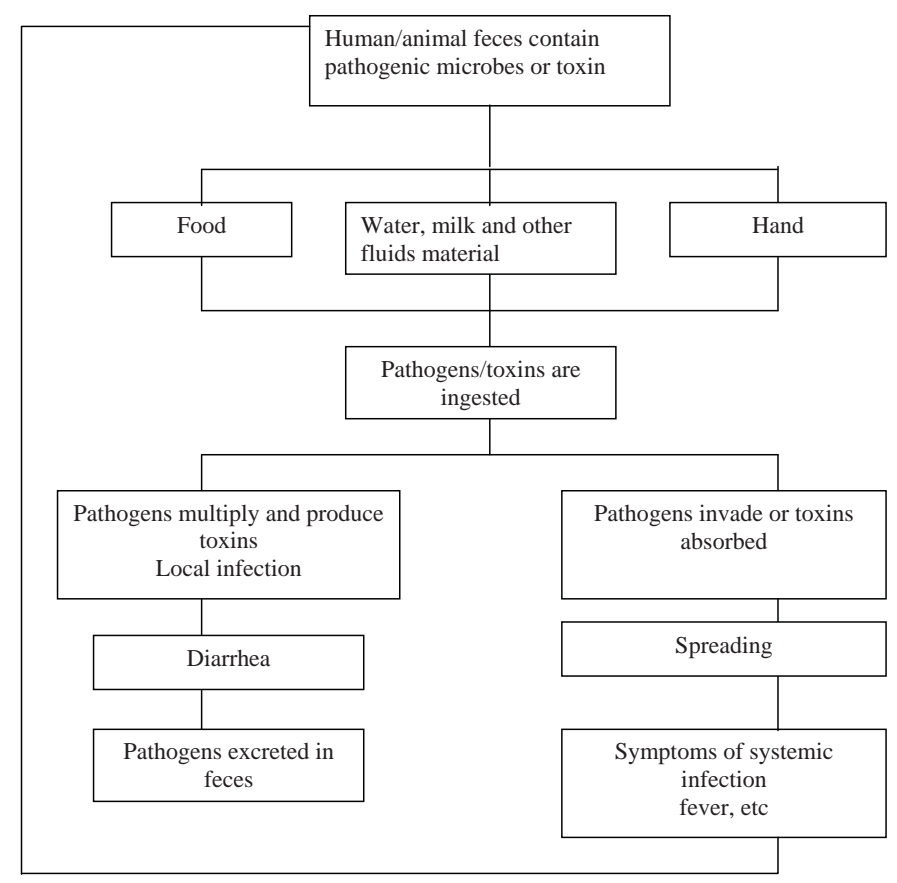

Figure 1. Localized and systemic infections of gastrointestinal tract (modified from ref 7) 
Our study revealed that the predominant bacteria that were isolated from the digestive tract were pathogenic Escherichia coli. However, we were only able to detect the pathogenic $E$. coli without determining the type of toxin produced, which was the limitation of this study. On the other hand, only one isolate of Salmonella paratyphi A was observed, while Rotavirus was not included in our study. Our results were different from another study conducted by Simadibrata et al, which found that chronic diarrhea causing microbes in adult were predominated by C. albicans (48.6\%) and pathogenic E. coli (34.8\%), while other bacteria represented low occurrences, i.e. $A$. aerogenes (3.6\%), M. tuberculosis (3.6\%), K. oxytoca (3.6\%), Salmonella paratyphi (2.9\%), K. ozaenae (2.2\%), K. pneumoniae (2.2\%), A. dispar (2.2\%), Geotrichum (1.5\%), Pseudomonas spp. (0.7\%), Y. enterocolitica (0.7\%), C. perfringens (0.7\%), S. sonnei $(0.7 \%)$ and $S$. flexneri $(0.7 \%) .^{10}$

Olowe et $\mathrm{al}^{11}$ found that $E$. coli isolated from human clinical samples in Nigeria were resistant to tetracycline (91.6\%), ampicillin (86.7\%), sulphonamide (77.8\%), cotrimoxazole (58.5\%), cefuroxin (57.8\%) and gentamicin (39.3\%). More than 64\% isolates were multi-drug resistant against 7 antibiotics tested. ${ }^{11}$ Sang et al studied the association of multi-drug resistant enteroaggregative $E$. coli with persistent diarrhea in Kenyan children, and they found that E. coli O44 was resistant to tetracycline, ampicillin, erythromycin, trimethoprim-sulphamethoxazole, and amoxillin/clavulanate. ${ }^{11}$ Our study showed a slightly different resistance pattern, as we observed a reduced sensitivity of E.coli against some antibiotics such as ticarcillin, trimethoprim/sulfamethoxazole, sulbenicillin and amoxicillin.

In conclusion, in this study, gastrointestinal tract infection was mainly due to pathogenic Escherichia coli. This microbe showed reduce sensitivity against amoxicillin, sulbenicillin, ticarcillin, and trimethoprim/ sulfamethoxazole.

\section{REFERENCES}

1. Nester EW, Anderson DG, Roberts CE Jr., Nester MT. Digestive system infection. In: Nester EW, Anderson DG, Roberts CE Jr., Nester MT. Microbiology a human prospective. $5^{\text {th }}$ ed. New York: Mc Graw Hill; 2007. p. 609-37.
2. Guerrant RL, Hughes JM, Lima NL, Crane J. Diarrhea in developed and developing countries: magnitude, special settings, and etiologies. Rev Infect Dis. 1990 Suppl 1:S41-50.

3. Snyder JD, Merson MH. The magnitude of the global problem of acute diarrhoeal disease: a review of active surveillance data. Bull World Health Organ 1982;60(4):1[about 9 p]. [cited 2010 June 3]. Available from www.ncbi.nlm.nih.gov/pubmed/pmc/articles/PMC 2536091/pdf/bull who 00106-0155.pdf.

4. Kosek M, Bern C, Guerrant RL. The global burden of diarrhoeal disease, as estimated from studies published between 1992-2000. Bull World Health Organ. 2010;81(3):197-204.

5. Mandeville KL, Krabshuis J, Ladep NG, Mul M, Khan SA. Gastroenterology in developing countries: issues and advances. World J Gastroenterol. 2009 ;15(23):1 [about 16 p.].[cited 2010 June 3] Available from www.ncbi.nl.nih. gov/pubmed/19533805.

6. Kcom [Internet]. Chamberlain NR. Gastrointestinal and hepatobiliary infections. c2009 - [cited 2009 Jan 12]. Available from http://www.kcom.edu/faculty/chamberlain/ website/lectures/lecture/gi1.htm.

7. Mims C, Dockrell HM, Goering RV, Roitt I, Wakelin D, Zuckerman. Gastrointestinal tract infections. In: Mims C, Dockrell HM, Goering RV, Roitt I, Wakelin D, Zuckerman. Medical Microbiology. $3^{\text {rd }}$ ed. Edinburgh. Elsevier-Mosby; 2004. p. 277-312.

8. Adln [internet].Wasito, Bagus E. Intestinal pathogens' pattern isolated from diarrheal feces in hospitalized children under two years old [Pola patogen usus yang diisolasi dari tinja diare pada anak rawat inap di bawah umur dua tahun]. 2003- [cited 2009 Apr 3]. Available from: http://adln.lib. unair.ac.id/go.php?id=jiptunair-gdl-res-2003-wasito2c-791-t inja\&PHPSESSID=e99ecec43aeb91a73c0e368ce140cf5f .

9. Omololu-Aso J, Adejuwon AO, Omololu-Aso OO, Akinbo OM, Kolawole DO. Antibiotics susceptibility of a strain of Salmonella isolated from an infant presented with diarrhea in Ile-Ife, Nigeria. Int J Med Med Sci. 2010; 2:167-70.

10. Simadibrata M, Tytgat GNJ, Yuwono V, Daldijono, Lesmana LA, Syam AI, et al. Microorganisms and parasites in chronic infective diarrhea. Acta Med Indones/ J Intern Med. 2004; 36: 211-4.

11. Olowe OA, Okanlaawon BM, Olowe RA, Olayemi AB. Antimicrobial resistant pattern of Escherichia coli from human clinical samples in Osogbo, south western Nigeria. Afr J Microbiol Res. 2008; 2:8-11.

12. Sang WK, Oundo JO, Mwituria JK, Waiyaki PG, Yoh M, Iida T, et al. Multidrug-resistant enteroaggregative Escherichia coli associated with persistent diarrhea in Kenyan children. Emerg Infect Dis. 1997; 3: 373-4. [cited2009 Apr 3]. Available from: http://www.cdc.gov/ncidod/EID/vol3no3/ sang .htm. 